\title{
Utilizing a Mind Mapping Strategy to Develop EFL Preparatory Stage Students' Writing Skills
}

\author{
Prepared by
}

\section{Ibrahim Mohamed Mohamed Saleh}

\author{
An EFL Teacher
}





\begin{abstract}
:
The main purpose of the current study was to investigate the effect of mind mapping strategy on developing 46 randomly selected EFL preparatory stage students' writing skills from Rabaa El Adawia Preparatory School, Kafr Saqr Educational Directorate, Sharkia Governorate in the second semester of the academic year 2019-2020. The researcher adopted quasi experimental design. The participants of the study were equally divided into the experimental and control groups. To achieve the purpose of the study, the researcher designed an EFL writing skills questionnaire, an EFL writing pre-posttest, and a rubric. The experimental group was taught by the use of mind mapping strategy while the control group received regular instruction. The results of the statistical analysis indicated that the experimental group writing skills developed as a result of utilizing mind mapping strategy. So, the researcher recommended that mind mapping activities should be integrated within the learning curriculum. It is suggested that further studies should investigate the relationship between mind mapping strategy and other writing skills, i.e. critical and creative writing at various educational stages.
\end{abstract}

Key words: Mind Mapping Strategy, EFL writing skills 


\subsection{Introduction}

Writing not only plays an important role in constructing knowledge but also in supporting thinking and negotiating skill for English language learner. meaning. Writing is an important skill that most probably all students should take care the is It exams depend mainly on writing ability. Being a of because productive language skill, writing focuses on either the process of writing or the final product.

Writing is a continuing process of discovering how to find the most effective language for communicating one's thoughts and feelings. Writing is very important for communication. It creates a communication channel between the writer and the reader.

Writing is an essential part of any lesson, not only in language class, but also in other classes such as Arabic, Science, History and Mathematics etc. For students, writing is a necessity that serves as one predictor of academic success which depends on an adequate degree of writing fluency. Writing refers to the domain of language proficiency that encompasses how students engage in written communication in a variety of forms for a variety of purposes and audiences.

Zimmerman \& Kitsantas ( 2002 ) showed that writing is one of the ways to convey an idea or a message. It is the art of thinking and feeling the words and ideas. Writing helps students represent and shape their experiences. It is a process that has

been related to the mental abilities of the students.

Heaton ( 1998 ) indicated that writing sub-skills are complex and sometimes difficult to teach, requiring mastery not only of grammatical and rhetorical device but also of conceptual and judgmental elements.

Harmer (1998) believed that students need to know how to write letters, how to put written reports together, how to reply to advertisements and increasingly, how to write using 
electronic media. They need to know some of writing special conventions ( punctuation, paragraph, construction, etc. ). The reason for teaching writing to students of English as a foreign language include reinforcement, language development, language style, and most importantly writing as a skill in its own right.

Byrne (1991) classified four sub-skills of writing:

- Grammatical skills: The ability to write correct sentences.

- Stylistic skill: The ability to manipulate sentences and use language effectively.

- Mechanical skills: The ability to use correctly those conventions peculiar to the written language, e.g. punctuation, spelling, etc.

- Judgment skills: The ability to write in an appropriate manner for a particular purpose with a particular audience in mind, together with the ability to select, organize and order relevant information.

Byrne ( 1997 ) divided the problems that make writing difficult into three categories. The first, he calls psychological, caused by lack of interaction and feedback between the reader and the writer. The second category consists of linguistic problems. Unlike speech in which spontaneous errors can be tolerated, writers have to express themselves in a clearer and more grammatical manner in order to compensate for the absence of certain features of spoken language. The third category consists of cognitive problems; i.e. Writing has to be taught through formal instruction. The organization framework for ideas in written communication has to be mastered. The complexity of the composing process is also due to the fact that it includes three main areas of choice : the ideas to be expressed, how to organize those ideas, and how to express them. The difficulty, therefore, lies in "invention " ( what to 
say ), " arrangement " ( the organization of what is said), and " style" (the expression of ideas with acceptable diction and grammar ).

The EFL students in general, and the EFL preparatory stage students in particular seem to be lacking the writing skills necessary for their academic progress. This was concluded through the researcher's experience in EFL teaching.

According to Oxford (1990), a specific strategy can make learning easier, faster and more enjoyable, and according to Buzan \& Buzan (1993) the human brain works sporadically, jumping from one topic to another. Thus, a better technique than a linear outline is to use a multi-dimensional outline which allows learners to put down their ideas in the form of free diagrams. This form is called Mind Mapping.

Mind Mapping is one kind of brain- based learning, that allows learners to view a whole image rather than information in parts. Brain-based learning takes the interest of the teacher and seats the student at the focus of learning. Brain-based learning strategies are learner centered and are planned to increase content retention from short-term to long-term memory( Restaino, 2011 ).

Budd ( 2004 ) referred to mind mapping as a graphic organizer in which the major categories radiate from the central image and lesser categories are portrayed as branches of larger branches. It can be used to generate ideas, take notes, develop concepts and ideas, and improve memory (Buzan, 2000 ). It is an illustrative tool that assists with managing thought, directing learning, and making connections ( Stephens, \& Hermus, 2007 ). It is a good way to introduce an overall topic, increase student involvement, and get thoughts down quickly. It also cuts across ability levels and encompasses all subject matters ( Goldberg, 2004 ).

Moreover, Balim, Evrekli and Aydin ( 2007 ) argued that Mind Mapping is an effective brain based visual technique that 
helps individuals actively use their right as well as their left brains by using their associations of the concepts and ideas and the elements of the image, expression, shape, size and color.

Buzan (2002) stated that Mind Mapping is a powerful graphic technique which provides a universal key to unlock the potential of the brain. It is a visual map of ideas, laid out in a radial format around a central thought and it involves a unique combination of imagery, color, and visual-spatial arrangement which is proven to significantly improve recall when compared to conventional methods of note-taking and learning by rote. It needs imagination and association to activate the brain in remembering something.

Howitt ( 2009 ) clarified that Mind Maps have been an effective tool for teaching and learning in both primary and secondary schools for many years. Additionally, it helps students associate ideas, think creatively, and make connections that might not otherwise make sense (Buzan, 2010).

Alamsyah ( 2009 ) explained that Mind Maps work well as their visual design enables students to see the relationship between ideas, and encourages them to group certain ideas together as they proceed. Also, Mind Maps work especially well when created in groups. In addition, the Mind Mapping strategy can be used to explore almost any topics in writing and also used in every kind of writing such as: narrative, descriptive, recount, persuasive, argumentative, essay, etc. Students can improve their ideas and lend themselves to discussing ideas in groups in order to increase students' interest of learning

English especially in writing skill.

As illustrated by Li, Yang \& Chen ( 2010 ), Mind Mapping is useful for the building of knowledge and understanding ideas association and vocabulary learning. It has been studied in areas such as: spelling, categorization, synonyms and free association. 


\subsection{Context of the problem:}

The researcher as an EFL teacher observed that the preparatory stage students have got low points in most of writing skills. The researcher reviewed the previous studies that assured the persistence of EFL students' lack of writing skills. Besides, interviews were also administered to EFL teachers in some preparatory schools. They confirmed that most students lack

Table (1): results of the pilot study:

\begin{tabular}{|r|r|}
\hline The writing skills & frequency \\
\hline Writing minimum six sentences for a paragraph or a letter. & $25 \%$ \\
\hline Communicating ideas and purpose of writing clearly to the \\
reader.
\end{tabular}

A pilot study was conducted in order to affirm the problem on a real scientific basis on forty preparatory students through a writing test. The test was administered to assess the students' actual level in writing skills. The results, explained above, of this test indicated that the first year preparatory school students had problems in writing skills.

\subsection{Statement of the problem:}

In the light of the previous discussion, the problem of the current study could be stated in the poor performance of first year students in EFL writing skills. Therefore, this study is an attempt to 
develop these skills for the EFL First year preparatory stage students

\subsection{Questions of the study:} adopting the mind mapping strategy.

In an attempt to overcome this problem, the following main question was addressed:

What is the effect of a Mind Mapping strategy on developing some EFL writing skills of the first year preparatory stage students?

The following sub questions can be derived from this main question:

1- What are the appropriate EFL writing skills required for the first year preparatory stage students ?

2- To what extent do students perform these writing skills?

3- How can the Mind Mapping strategy be used to develop the first year preparatory stage students' writing skills?

\subsection{Purpose of the study:}

This study aimed at investigating the effect of the Mind Mapping strategy on developing some writing skills for the

\subsection{Significance of the study:} first year preparatory stage students.

The results of the study were hopefully expected to be useful to

a) EFL Students :

- Improve their writing skills.

- Motivate them to write in English correctly and accurately.

b) EFL Teachers :

- Encourage them to use the Mind Mapping strategy in their classes, so that they may achieve the learning process goals.

c) Supervisors and curriculum designers :

- Utilize Mind Mapping in planning and designing writing activities suitable for the first year preparatory 


\section{ILA الجمعية المصرية للقراءة والمعرفة عضو الجمعية الدولية للمعرفة}

stage students as well as in evaluating their writing performance.

\subsection{Delimitations of the study:}

This study would be delimited to:

- A random sample of first year preparatory Stage students from Rabaa El Adawia Preparatory School, Kafr Saqr Educational Directorate, Sharkia Governorate.

- Some writing skills required for the first year preparatory stage students which will be determined by jury members.

Some units and lessons from Students' Book and Workbook: New

Hello English for Preparatory Schools Year One.

\subsection{Procedures of the study:}

In order to answer the questions of the study, the following procedures will be conducted:

1- Reviewing literature and previous studies related to the study variables;

a- Indep. (Mind Mapping) to frame the experiment.

b- Dep. (writing skills) to conclude skills.

2- Designing a writing questionnaire and approving it via TEFL jury members to state the most important writing skills suitable for the first year preparatory school students.

3- Designing the writing pre-posttest and approving it through TEFL jury members to identify its validity.

4- Designing a Mind Mapping strategy containing the writing portion in the student's book and workbook.

5- Selecting the study participants randomly from first year preparatory school students and dividing them into experimental and control groups. 


\section{الجمعية المصرية للقراءة والمعرفة عضو الجمعية الدولية للمعرفة ILA}

6- Pre-administering the writing test to both groups to identify the students' real level concerning these skills.

7- Teaching the experimental group only using the Mind Mapping strategy.

8-Post-administering the writing test to both groups.

9- Comparing results of both administrations.

10- Using suitable statistical methods to measure the effect of the Mind Mapping strategy on developing the first year preparatory school students' writing skills.

11- Discussing the results of the study.

12- Providing conclusion, recommendations and suggestions for further studies.

\subsection{Data Analysis}

\section{Verifying the study Hypotheses}

To determine whether participants overall writing skills improved after implementing the experimental treatment using mind mapping strategy, the hypotheses of the study were tested by using the Statistical Package for Social Sciences (SPSS vre26) Program. ttest was used in order to check whether there were any differences between the means of scores of the treatment group on the pre and the post administrations of the study instruments.

\section{Hypothesis (1):}

"There would be a statistically The first hypothesis states that significant difference between the mean of scores of the experimental and the control groups in the post administration of the EFL writing skills test, in favor of the experimental group results."

To verify this hypothesis, the researcher used the Independent sample t-test to compare the mean scores of the experimental group students who used mind mapping strategy with those of the control 
group students who used the traditional method, in the post-test. The results are presented in the following table.

Table (4): Both groups post writing test results.

\begin{tabular}{|c|c|c|c|c|c|c|c|}
\hline Skill & Group & $\mathbf{N}$ & $\mathbf{M}$ & S.D & D. $\mathbf{f}$ & t-value & sig \\
\hline \multirow[b]{2}{*}{ 1- content } & Control & 23 & 3.2 & .94 & \multirow{8}{*}{44} & \multirow[t]{2}{*}{4.9} & \multirow[t]{2}{*}{0.00} \\
\hline & experimental & 23 & 4.6 & .99 & & & \\
\hline \multirow{2}{*}{ 2- grammar } & Control & 23 & 2.8 & 1.0 & & \multirow[t]{2}{*}{4.2} & \multirow[t]{2}{*}{0.00} \\
\hline & experimental & 23 & 4.0 & .93 & & & \\
\hline \multirow[t]{2}{*}{ 3- mechanics } & Control & 23 & 3.8 & .83 & & \multirow[t]{2}{*}{4.3} & \multirow[t]{2}{*}{0.00} \\
\hline & experimental & 23 & 5.0 & .93 & & & \\
\hline \multirow{2}{*}{$\begin{array}{l}\text { Overall EFL } \\
\text { writing skills }\end{array}$} & Control & 23 & 9.8 & 2.7 & & \multirow[t]{2}{*}{4.8} & \multirow[t]{2}{*}{0.00} \\
\hline & experimental & 23 & 13.6 & 2.7 & & & \\
\hline
\end{tabular}

The table above indicates that the mean scores of the experimental group students are higher than those of the control group in the overall EFL writing skills and its sub-skills, where tvalue is, (4.8) for overall EFL writing skills, (4.9) for content, (4.2) for grammar, (4.3) for mechanics , which is significant at 0, 01 level of significance. Therefore, this hypothesis was confirmed. These differences can be attributed to mind mapping strategy.

\section{Hypothesis (2):}

The second hypothesis states that "There would be a statistically significant difference between the mean of scores of the experimental group in the pre and post administrations of the writing skills test results, in favor of the post administration.

To verify this hypothesis, the researcher used the paired sample ttest to compare the mean scores of the experimental group who used 
mind mapping strategy in the pre and post-test. The following table includes the results.

Table (5): The Pre-Post writing test results of both groups

\begin{tabular}{|c|c|c|c|c|c|c|c|}
\hline Skill & Group & $\mathbf{N}$ & M & S.D & D. $f$ & t-value & sig \\
\hline \multirow[b]{2}{*}{ 1- content } & Pre & 23 & 3.0 & .90 & \multirow{8}{*}{22} & \multirow[t]{2}{*}{11.1} & \multirow[t]{2}{*}{0.00} \\
\hline & Post & 23 & 4.6 & .99 & & & \\
\hline \multirow[t]{2}{*}{ 2- grammar } & Pre & 23 & 2.6 & .78 & & \multirow[t]{2}{*}{13.6} & \multirow[t]{2}{*}{0.00} \\
\hline & Post & 23 & 4.0 & .93 & & & \\
\hline \multirow[t]{2}{*}{ 3- mechanics } & Pre & 23 & 3.2 & .67 & & \multirow[t]{2}{*}{15.4} & \multirow[t]{2}{*}{0.00} \\
\hline & Post & 23 & 5.0 & .93 & & & \\
\hline \multirow{2}{*}{$\begin{array}{l}\text { Overall EFL } \\
\text { writing skills }\end{array}$} & Pre & 23 & 8.7 & 2.0 & & \multirow[t]{2}{*}{19.4} & \multirow[t]{2}{*}{0.00} \\
\hline & Post & 23 & 13.6 & 2.7 & & & \\
\hline
\end{tabular}

The table above indicates that the mean scores of the experimental group students in posttest are higher than in pretest in the overall EFL writing skills and its sub-skills, where t-value is, (19.4) for overall writing skills, (11.1) for content, (13.6) for Grammar, (15.4) for mechanics, which is significant at 0,01 level of significance. Therefore, this hypothesis was confirmed. These differences can be attributed to Mind mapping strategy.

\section{Hypothesis (3):}

Mind mapping strategy would The third hypothesis states that" be effective in developing the EFL Preparatory stage students' writing skills."

To verify this hypothesis, the researcher calculated the effect size by using the paired sample t-test to compare the scores of the experimental group in the students' EFL writing skills and motivation in the pre and the posttest using Cohen's formula. 
Table (6): The referential framework for identifying the effect size

\begin{tabular}{|c|r|}
\hline Effect size & Interpretations \\
\hline From 0.2 till less than 0.5 & Small \\
\hline From 0.5 till less than 0.8 & Medium \\
\hline From 0.8 or more & Large \\
\hline
\end{tabular}

Table (7): The effect size of the experimental group in EFL writing skills as a whole in the pre and the post test.

\begin{tabular}{|c|c|c|c|c|c|c|c|}
\hline Skill & Test & $\mathbf{N}$ & M & S.D & t-value & $\begin{array}{r}\text { Eta } \\
\text { square }\end{array}$ & $\begin{array}{r}\text { Effect } \\
\text { size }\end{array}$ \\
\hline \multirow[b]{2}{*}{ 1- content } & Pre & 23 & 2.9 & .90 & \multirow[t]{2}{*}{11.1} & \multirow[t]{2}{*}{.44} & 0.89 \\
\hline & Post & 23 & 4.6 & .99 & & & Medium \\
\hline \multirow[t]{2}{*}{ 2- grammar } & Pre & 23 & 2.6 & .78 & \multirow[t]{2}{*}{13.6} & \multirow[t]{2}{*}{.42} & 0.85 \\
\hline & Post & 23 & 4.0 & .93 & & & Medium \\
\hline \multirow[t]{2}{*}{ 3- mechanics } & Pre & 23 & 3.2 & .67 & \multirow[t]{2}{*}{15.4} & \multirow[t]{2}{*}{.55} & 1.1 \\
\hline & Post & 23 & 5.0 & .93 & & & ge \\
\hline \multirow{2}{*}{$\begin{array}{l}\text { Overall EFL } \\
\text { writing skills }\end{array}$} & Pre & 23 & 8.7 & 2.0 & \multirow[t]{2}{*}{19.4} & \multirow[t]{2}{*}{.52} & \multirow{2}{*}{$\begin{array}{r}1.04 \\
\text { Large }\end{array}$} \\
\hline & Post & 23 & 13.6 & 2.7 & & & \\
\hline
\end{tabular}

\section{Significant at $(0,01)$}

Table (7) indicates that the effect size of the experimental group students in the post test are greater and higher than those of the prescores in overall EFL writing skills, where the effect size is (1.04) for overall EFL writing skills, (0.89) for content, (0.85) for grammar, (1.1) for mechanics, which is significant at 0,01 level of significance. Therefore, this hypothesis was confirmed. These differences can be attributed to mind mapping strategy. According to the findings of Cohen's formula and the interpretations of the effect size, the percentage 1.04 indicated that 
mind mapping strategy had an effect on improving the students' EFL writing skills.

\subsection{Results of the study:}

The results of the current study showed that:

1- The experimental group outperformed the control one on the writing posttest as a whole and its sub-skills. Hence, the significant differences are due to exposing this group to the mind mapping strategy.

2- The obtained results proved significant differences between the pre and the post administrations of the writing skills test to the experimental group favoring the post results.

3- The mind mapping strategy proved to be statistically and educationally significant in developing participants' writing skills.

\subsection{Interpretation of the results:}

Results of the current study are discussed with reference to the hypotheses validation and the relevant literature.

After the administration of the mind mapping strategy, the experimental participants achieved progress and development in writing skills. This could be attributed to the nature of the mind mapping strategy. This strategy has been based on the notion that teacher and students work together through the activities incorporated in the strategy such as brainstorming, discussing and question.

The different activities written by the experimental participants and the response written by the teacher provided a means for enabling them to develop the writing skills such as content, grammar and mechanics in this way:

a- The researcher/teacher in his response to the participants' activities presented comments on what they wrote down, through which questions were aroused about parts that were not clear or needed more clarification. This enabled the participants to write 


\section{الجمعية المصرية للقراءة والمعرفة عضو الجمعية الدولية للمعرفة ILA}

more through answering the teacher's comments. This consequently, increased quantity of writing and generated more ideas related to the topic which in turn improved the content of writing and enabled them to set one main idea to the topic with relevant supporting details.

b- The researcher/teacher in his response modeled punctuation, spelling and grammatical correctness indirectly. Moreover, brainstorming and whole class discussion played an important role in developing the content of writing as these activities enabled participants to generate relevant ideas and support the main one. Besides allowing participants to read proved that oral reading has a positive effect on developing the purpose, content and vocabulary skills of the participants' writing as this activity gave them the opportunity to:

- Identify the main idea of writing,

- Use well-chosen vocabulary, idioms and expressions, and

- Write a proper form of paragraphs.

The scores that the participants got in each sub-skill of writing in the evaluation sessions helped them to be better in using them. In addition, conducting brief class lessons on common errors and giving the participants scaffolding writing exercises enabled them to better perform the writing skills necessary for them.

The justification of the results above could be that mind mapping strategy exposed the participants to a variety of vocabulary, structure and language style related more closely to their needs in the real world; helped in developing their writing skills. Mind mapping activities (a) increased their knowledge of vocabulary items needed in real situations, (b) introduced them to how language is used in the real world, (c) improved their language proficiency as well as writing performance, (d) were interesting, (e) fulfilled their needs, and (f) enabled them to enhance their writing styles. 
The change in teacher's role, through the mind mapping strategy from an evaluator of students' writing to a facilitator and partner who helped participants understand how to write, affected the relationship between the researcher and participants which in turn gave them a sense of self-confidence and autonomy in their abilities as writers. Thus, the participants no longer feared writing. Creating a friendly, non-threating, interactive, fear-free, encouraging, motivating atmosphere based on mutual interaction between the researcher and the participants in the classroom made them feel comfortable and motivated with writing.

After implementing the suggested strategy, the participants started to be trustful and they had more courage to express their ideas; that is because the mind mapping strategy design developed their skills and abilities to write and gave them the feeling of selfconfidence and create a good learning atmosphere.

\subsection{Recommendations:}

In the light of the results of the study, the following could be recommended:

1- Practicing writing should include mind mapping activities to enable the students to write in an interactive way.

2- EFL teachers should promote students' interest/attitude toward English language learning by using the mind mapping strategy.

3- EFL students should learn how to use sentences in meaningful situations to develop their writing.

4- EFL teachers should offer strategies that help their students build confidence in their writing and provide them with opportunities to participate in various activities, and feel that their writing had a value.

5- EFL writing should be given greater emphasis as an act of communication. Students should be provided with 
opportunities to share with their teachers and discuss their writing with teachers and peers.

6- EFL teachers need to be provided with training to explore the usefulness of using mind mapping strategy to master its integration in their classrooms and learn about how to design mind maps to enhance their students' learning by adding a variety of activities and avoid monotony of teaching

7- Mind mapping activities should be integrated within the learning curriculum, relating them to the goals and objectives of the course.

8- EFL teachers should emphasize the development of the students' writing skills in the early educational stages to develop them in the following ones.

9- It is also recommended that teachers get trained to teaching writing as a process not as a product and adopting process writing in teaching writing skills as this approach offers students an outstanding opportunity to learn how to write and make writing easier and more interesting.

10- EFL students should be offered enough opportunities to practice writing, paying attention to the fact that writing is a developmental skill that improves gradually.

11-EFL students should get continuous feedback on their writing skills without the threat of face-to-face confrontation. This can be achieved through mind mapping strategy.

12-EFL teachers should change their role from examiners who evaluate students' writing to facilitators, consultants and organizers to the students' ideas, who help students improve their writing skills. In this way, the evaluation process will not be a frightening experience that causes them to avoid writing. 
13-In classroom setting, students should be grouped in different ways based on individuals, pairs, small groups or whole class mode

\subsection{Suggestions for further research:}

Out of the study delimitations and results, the following research areas can be suggested:

1- Investigating the relationship between mind mapping strategy and other writing skills, i.e. critical and creative writing at various educational stages.

2- Investigating the relationship between mind mapping strategy and other language skills, e.g. reading, speaking and listening.

3- Designing similar mind mapping strategy for students at different stages (primary, secondary and university).

4- Conducting more research using this strategy with other class categories in other courses of study.

5- Investigating the relationship between this mind mapping strategy and other variables, such as writing motivation, selfefficacy, reading awareness, reading comprehension, reading interests, and students' attitudes, towards studying English.

6- Investigating the relationship between other instructional strategies and students' writing skills.

7- Designing a course for training pre-service and in-service teachers to how to adopt the mind mapping strategy. 


\section{References}

Alamsyah, M. (2009): KiatJituMeningkatkanPrestasiDengan Mind Mapping.Yogyakara:MitraPelajar.

Balim, A.,Evrekli, E .,\& Aydin, G. (2007): The application of mind manager and mind mapping technique in science and technology education. International Educational Technologies Conference. Retrieved on June 26, 2011, from http: // academia.edu /papers1/in Cocept- MappingMind-Mapping.

Budd, J. (2004): Mind maps as classroom exercises. New York. Journal of Economic Education, 35, 1-34.

Buzan, T (1993). Mind map book. How to use radiant thinking to maximize your brains untapped potential.London:Pengum Group

Buzan, T. \& Buzan, B. (2000): The mind map book (Millenium Ed.).London: BBC

Buzan, T. (2002): How to mind map:Make the most of your mind and learn how to create, organize, and plan. London:

Martins the Printers.

Buzan, T. (2010): Buku Pintar Mind Mapping Untak Anak. Jakarta: PT Gramedia Pustaka Utama.

Byrne, D. (1991): Teaching writing skills. London: Longman Group UK limited. 
Byrne, D. (1997): Basic Comprehension Passages with Vocabulary Exercises. $\left(10^{\text {th }}\right.$ Ed.). Harlow, Activities and Recall

Essex, England: Longman Group UK limited.

Goldberg, C. (2004): Brain friendly techniques: Mind mapping school library Media Activities Monthly,21(3),22-24.

Harmer, J. (1998): How to teach English. England: Addison Wesley Longman.

Heaton, JB. (1998): Writing English Language Test. New York: Edinburg Gate.

Howitt, C. (2009): 3D mind maps: Placing young children in the centre of their own learning. Teaching Science-the Journal of the Australian.55 (2), 42-46.

Li, M., Yang, Y., \& Chen, H. (2010): Using Mind Maps as a strategy for vocabulary acquisition in Chinese Universities. In Computational Intelligence and Software Engineering (CISE), 2010 International Conference on (pp. 1-3) IEEE.

Oxford, R. (1990): Language learning strategies. New York, 3. Restaino, Rusti, RN, B.S.N., M.B.A. (2011): Gain attention, enhance memory, and

improve learning with brain-based strategies. The Journal of Continuing Education in Nursing, 42(5), 199- 200. doi.org/10.3928/00220124-20110421-04. 
Stephens, P. \& Hermus, C. (2007): Making art connections with graphic organizers. School Arts: The Art Education magazine for teachers.106, 8, 55

Zimmerman, B., and Kitsantas, A. (2002): Acquiring writing revision and self-

Regulatory skill through observation and emulation.

Journal of

Educational Psychology, 94, 660-668. 


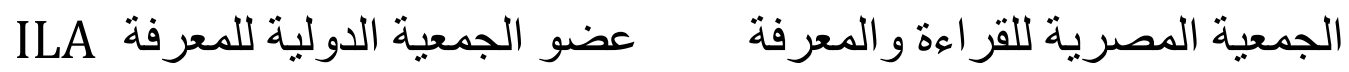

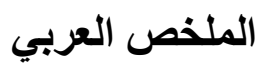

\section{استخدام استراتيجية الخرائط الذهنية في تنمية مهارات الكتابة باللغة الانجليزية كلغة اجنبية لاي طلاب المرحلة الاعدادية الطرية}

تمثل الدر اسة الحالية محاولة لتنمية مهار ات الكتابة باللغة الانجليزية كلغة اجنبية لاى 7؟ طالبا فى المرحلة الاعدادية تم اختيارهم عشو ائيا من مدرسة رابعة العدوية الإعدادية ، ادارة كفر صقر التعليمية ، محافظة الثرقية في الفصل الدراسى الثاني من

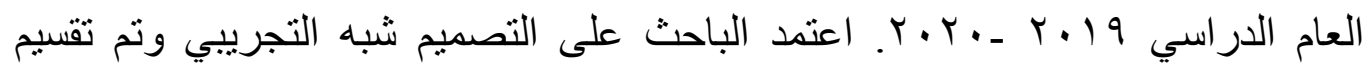
المشاركين في الدراسة بالتساوي إلى مجموعتين احدهما التجريبية والاخرى الضابطة. لتحقيق الغرض من الدراسة ، صمم الباحث استبيانًا لمهار ات الكتابة في اللغة الإنجليزية كلغة أجنبية ، واختبار قبلى بعدى فى الكتابة باللغة الإنجليزية كلغة أجنبية ، وقاعدة تقييه. تم التدريس للمجموعة التجريبية باستخدام استراتيجية الخرائط الذهنية بينما تلقت المجموعة الضابطة التدريس بالطريقة التقليدية. أشارت نتائج التحليل الإحصائي إلى أن

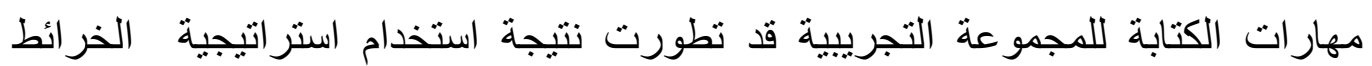
الذهنية لذا أوصى الباحث بضرورة دمج أنشطة استراتيجية الخر ائط الذهنية في مناهج التعلم. يقترح أن تبحث المزيد من الدراسات العلاقة بين استراتيجية الخرائط الذهنية ومهارات الكتابة الأخرى وبالاخص الكتابة النقدية والإبداعية في المراحل التعليمية

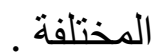

